\title{
EFFECT OF SELENIUM AND NANO-SELENIUM ON CISPLATIN-INDUCED NEPHROTOXICITY IN ALBINO RATS
}

\author{
M. M. A. SHAFAEE ${ }^{1}$, H. S. MOHAMED 2 , S. A. AHMED ${ }^{1}$, M. A. KANDEIL \\ ${ }^{1}$ Chemistry Department, Faculty of Science, Beni-Suef University, Egypt; \\ ${ }^{2}$ Research Institute of Medicinal and Aromatic Plants, Beni-Suef University, Egypt; \\ ${ }^{3}$ Biochemistry Department, Faculty of Veterinary Medicine, Beni-Suef University, Egypt; \\ e-mail: husseinshaban@science.bsu.edu.eg
}

Received: 05 July 2019; Accepted: 18 October 2019

Cisplatin is commonly used as a chemotherapeutic agent useful in the treatment of several forms of cancer, but its use is limited due to the undesirable side effects of nephrotoxicity. Most of the previous researches found a positive effect of using selenium as an antioxidant on the toxicity of cisplatin during short term administrations although the recommended dose regimen of cisplatin in chemotherapy is multiple successive administration every three or four weeks depending on the type of the tumor. The aim of this study was to examine the effects of long term usage of selenium or nano-selenium on cisplatin-induced nephrotoxicity in albino rats. Forty rats were divided into equal four groups, $1^{\text {st }}$ group as a control injected with normal saline, $2^{\text {nd }}$ group injected with cisplatin $6 \mathrm{mg} / \mathrm{kg}$ every 21 days for 70 days (experimental period), $3^{\text {rd }}$ group injected with cisplatin $6 \mathrm{mg} / \mathrm{kg}$ plus intramuscular injection $0.1 \mathrm{mg} / \mathrm{kg}$ selenium in the form of sodium selenite every 3 days during the experimental period, the $4^{\text {th }}$ group injected with cisplatin $6 \mathrm{mg} / \mathrm{kg}$ plus intramuscular injection $0.1 \mathrm{mg} / \mathrm{kg}$ nano-selenium every 3 days during the experimental period. The results indicated that selenium or nano-selenium exerted an antioxidant effect through increasing the level of antioxidant enzymes in both serum and kidney tissue, while, it shows a negative effect on kidney function through increasing serum urea and creatinine concentrations and causing abnormal morphology of kidney tissue for rats treated with cisplatin during experimental period.

Keywords: selenium, nano-selenium, cisplatin, nephrotoxicity.

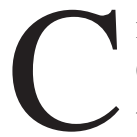

isplatin (cis-diammine-dichloroplatinum II, $\mathrm{CP}$ ) has been viewed as a standout amongst the best chemotherapeutic agents. Action has been exhibited against different types of tumors, especially of the neck and head $[1,2]$, ovarian [3, 4], testicular [5, 6], bladder [7, 8] esophageal $[9,10]$, and small cell lung malignant growths $[11,12]$. The clinical utilization of CP is frequently restricted because of its unfortunate side symptoms, nephrotoxicity and neurotoxicity being the most extreme and portion constraining ones [13]. CP-renal problems are related to expanded kidney vascular opposition and histological harm to proximal cylindrical cells [1416]. The cytotoxicity of CP is viewed as because of a blend of elements, including peroxidation of the cell membrane, mitochondrial brokenness, restraint of protein synthesis, and DNA damage [17, 18]. The most widely recognized antagonistic impact restricting the utilization of $\mathrm{CP}$ is nephrotoxicity that grows basically in the $\mathrm{S} 3$ segment of the proximal tubule [19]. Nevertheless, the significant confinement to utilize a high portion of cisplatin is its solid symptoms in the kidney and gastrointestinal tract $[20,21]$.

The pathogenesis of kidney harm brought about by $\mathrm{CP}$ is, for the most part, viewed as oxidative harm [3]. Injection of CP elevated lipid peroxide levels and a decline in the action of cell reinforcement resistan-

(C) 2019 Shafaee M. M. A. et al. This is an open-access article distributed under the terms of the Creative Commons Attribution License, which permits unrestricted use, distribution, and reproduction in any medium, provided the original author and source are credited. 
ce catalysts that avert or shield from lipid peroxidation in tissues [22]. Cisplatin is accumulated in the rounded epithelial cells of proximal kidney tubule, leading to nephrotoxicity, described by morphological pulverization of intracellular organelles, cell corruption, changes in the size and number of the mitochondrial and lysosomes vacuolization, loss of microvilli, followed by utilitarian modifications including hindrance of protein union, GSH exhaustion, lipid peroxidation and mitochondrial harm $[15,20,23]$.

Selenium is an essential trace element. It is a component of some selena proteins and enzymes like glutathione peroxidase. Selenium compounds are antioxidants which are much more potent than other antioxidants like vitamin $\mathrm{E}$ and vitamin $\mathrm{C}$ [24]. The nano-selenium has a pharmacological protection against various inflammatory and oxidative stress [25]. Selenium plays an important role in the management of the reactive oxygen species in colorectal cancer [26]. Since, the cisplatin-induced nephrotoxicity is caused mainly by the reactive oxygen species which are generated due to the leak of electrons from the mitochondrial respiratory chain as a result of the mitochondrial damage [27]. The organic forms of selenium are used to stop the progression of the generation of reactive oxygen species like diphenyl methyl selenocyanate [28]. 2-(5-selenocyanatopentyl)-benzo[de]isoquinoline 1,3-dione [29]. The selenium nanoparticles which are synthesized by Lactobacillus casei ATCC 393 shows a protective barrier against the effect of hydrogen peroxide in vitro [30]. The inorganic selenium like sodium selenite shows an ameliorative effect against cisplatin oxidative stress in short term studies. Injection $1.5 \mathrm{mg} /$ $\mathrm{kg}$ selenium with high dose VE $1000 \mathrm{mg} / \mathrm{kg}$ combination seem to produce significant improvement on anti oxidant enzymes in rats treated with cisplatin [31]. Similar effects were found when treated rats with single dose from cisplatin $(7 \mathrm{mg} \mathrm{CP} / \mathrm{kg})$ and selenium $\left(6 \mathrm{mg} / \mathrm{kg}\right.$ as $\left.\mathrm{Na}_{2} \mathrm{SeO}_{3}\right)$, alone or combination [32]. Defensive impact against cisplatin nephrotoxicity when utilizing single portion of sodium selenite were examined [33]. Although the beneficial effects of the use of selenium either in organic form or inorganic form, it's use practically is diminished as all of the cisplatin treatment protocols recommends the multiple successive administration So, that, this experiment was intended to think about the impact of utilizing selenium or nano-selenium form of sodium selenite during long term administration with mul- tiple successively use of cisplatin against cisplatin induced renal failure.

\section{Materials and Methods}

Animals. Forty male albino rats (average weight 150-180 g) were gotten from the Reproducing Unit of the Egyptian Association for the Biological and Vaccine Production were utilized in this study. Rats were housed at a temperature of $23-25^{\circ} \mathrm{C}$. They were kept in appropriate cages with natural day/night. Animals were permitted ad libitum access to water and feed pellets, and underwent a 1-week adaptation period prior to the beginning of the experiment. Animals were distributed into four equal groups (10 rats per each). Group 1 was injected by normal saline and severed a negative control, group 2 was intraperitoneally injected with cisplatin $6 \mathrm{mg} / \mathrm{kg}$ b.wt. every 21 days for 70 days and severed a positive control, group 3 was intraperitoneally injected with $6 \mathrm{mg}$ cisplatin every 21 days plus intramuscular injection of sodium selenite $0.1 \mathrm{mg} / \mathrm{kg}$ b.wt. as micro-selenium source every 3 days during the experimental period and group 4 was intraperitoneally injected with $6 \mathrm{mg}$ cisplatin every 21 days plus intramuscular injection of nano-selenium $0.1 \mathrm{mg} / \mathrm{kg}$ b.wt. every 3 days during the experimental period. The humane slaughtering procedure was conducted at the Faculty of Science research abattoir, Beni-Suef University, Egypt. All animal procedures were performed in accordance with the standards set forth guidelines for the care and use of experimental animals by the Animal Ethics Committee of Zoology Department, Faculty of Science, Beni-Suef University (Approval number is BSU/FS/2014).

Chemicals. Cisplatin Glass vial contains active substance of cisplatin $50 \mathrm{mg} / 50 \mathrm{ml}$, Mylan S.A.S. France. Sodium selenite $\left(\mathrm{Na}_{2} \mathrm{SeO}_{3} \cdot 5 \mathrm{H}_{2} \mathrm{O}\right)$, was purchased from Fisher Scientific office, Sodium selenite nano powder, $100 \mathrm{~nm}$, A.R, ACS, product cod; S7542/025.

Biochemical analysis. At the end of the experiment, blood samples were taken from the aorta and were investigated for renal disability markers. Urea and creatinine levels were estimated in serum by utilizing a programmed biochemical analyzer (biosystems automated reagent Kits obtained from Costa Brava 30, chemical company, Barcelona, Spain).

Some antioxidant enzymes were determined in both serum and kidney tissue. MDA, SOD and CAT were determined by using colorimetric method [34], while GPX by UV method [35]. 
Histological analysis. Para-formaldehyde-fixed kidney tissues were got dried out in rising reviewed arrangement of liquor and installed in paraffin. Kidney tissue examples were cut into cuts of $5 \mu \mathrm{m}$ thickness utilizing a HistoRange microtome as indicated by traditional recoloring conventions. Histological Assessment For light tiny assessment, kidney tests were fixed in $10 \%$ supported formalin for $48 \mathrm{~h}$ and prepared for routine paraffin implanting. For general morphological assessment, around 4- $\mu \mathrm{m}$ thick areas were recolored with hematoxylin and eosin $(\mathrm{H}$ and E). In both of the recoloring method, no less than 5 comparative infinitesimal regions were watched. The majority of the recolored areas were watched and shot with an advanced camera (Olympus C-5060, Tokyo, Japan) appended to a photomicroscope in the faculty of veterinary medicine, Beni-suef university.

Statistical analysis. Data were expressed as means \pm SE and statistical analyses were performed with SPSS Version 22.0 for Windows (SPSS, 2013). Duncan's New Multiple Range Test (Duncan, 1955) of the same SPSS program was applied to determine significant differences among all tested groups.

\section{Results and Discussion}

The effect of intraperitoneal injection of cisplatin, cisplatin co-administrated with selenium and cisplatin co-administrated with nano-selenium are discussed through the interpretations of both, both the biomarkers of oxidative stress plus, the biochemi- cal markers expressing the healthy and histological pathology status of the kidney.

Effect of different selenium forms on oxidative stress and some antioxidant enzymes. Effect of treatments on malondialdehyde (MDA) as oxidative stress marker and some antioxidant enzymes (glutathione peroxidase, GPX; superoxide dismutase, SOD and catalase, CAT) activities are presented in Table. The present data indicated that there are significant $(P<0.05)$ changes in all enzymes upon treatments with $\mathrm{CP}$ and Se.

The injected cisplatin (positive control group) at a dose of $6 \mathrm{mg}$ cisplatin $/ \mathrm{kg} \mathrm{b}$. wt. every 21 days for 70 days induced significant increase $(P<0.01)$ in the level of MDA for serum and kidney tissue (17.63 and $17.55 \%$, respectively), while CAT (-45.69 and $-17.80 \%$, respectively) activity, GPX activity $(-25.38$ and $-20.00 \%$, respectively) and SOD activity $(-12.70$ and $-13.53 \%$, respectively) were significantly decreased $(P<0.01)$.

Cisplatin-treated animals with both selenium and nano-selenium at a dose of $0.1 \mathrm{mg} / \mathrm{kg}$ as selenium sources every 3 days for 70 days were recorded significant increase $(P<0.01)$ in the content of CAT for serum and kidney tissue (14.29 and $57.67 \%$ in serum, 6.55 and $15.48 \%$ in tissue, respectively), the activity of GPX (4.59 and $20.07 \%$ in serum, 8.03 and $20.00 \%$ in tissue, respectively) and the activity of SOD (8.02 and $13.38 \%$ in serum, 2.31 and $12.22 \%$ in tissue, respectively) with a significant decrease

Oxidative stress marker and some antioxidant enzymes activities in serum and kidney tissue as affected by different treatments

\begin{tabular}{l|c|c|c|c}
\hline \multirow{2}{*}{ Treatments } & \multicolumn{4}{c}{ Activity of enzymes } \\
\cline { 2 - 4 } & MDA, nmol/ml & CAT, nmol/ml & GPX, mU/ml & SOD, Ul/ml \\
\hline \multirow{4}{*}{ Control } & $9.13 \pm 0.11^{\mathrm{c}}$ & $165.71 \pm 1.65^{\mathrm{a}}$ & $15.76 \pm 0.06^{\mathrm{a}}$ & $126.26 \pm 0.61^{\mathrm{a}}$ \\
Cisplatin & $10.74 \pm 0.21^{\mathrm{a}}$ & $90.00 \pm 0.16^{\mathrm{c}}$ & $11.76 \pm 0.22^{\mathrm{b}}$ & $110.23 \pm 2.32^{\mathrm{c}}$ \\
Selenium & $9.83 \pm 0.17^{\mathrm{b}}$ & $102.86 \pm 1.65^{\mathrm{c}}$ & $12.30 \pm 1.01^{\mathrm{b}}$ & $119.07 \pm 0.87^{\mathrm{b}}$ \\
Nano-selenium & $9.25 \pm 0.10^{\mathrm{c}}$ & $141.90 \pm 10.08^{\mathrm{b}}$ & $14.12 \pm 0.32^{\mathrm{a}}$ & $124.98 \pm 2.38^{\mathrm{a}}$ \\
& & Kidney tissue & \\
Control & $19.72 \pm 0.16^{\mathrm{c}}$ & $415.34 \pm 0.61^{\mathrm{a}}$ & $26.00 \pm 0.22^{\mathrm{a}}$ & $263.12 \pm 5.00^{\mathrm{a}}$ \\
Cisplatin & $23.18 \pm 0.11^{\mathrm{a}}$ & $341.43 \pm 4.12^{\mathrm{d}}$ & $20.80 \pm 0.39^{\mathrm{c}}$ & $227.53 \pm 1.75^{\mathrm{b}}$ \\
Selenium & $21.85 \pm 0.41^{\mathrm{b}}$ & $363.81 \pm 5.79^{\mathrm{c}}$ & $22.47 \pm 0.66^{\mathrm{b}}$ & $232.78 \pm 13.11^{\mathrm{b}}$ \\
Nano-selenium & $20.21 \pm 0.22^{\mathrm{c}}$ & $394.29 \pm 6.60^{\mathrm{b}}$ & $24.96 \pm 0.35^{\mathrm{a}}$ & $255.34 \pm 5.80^{\mathrm{a}}$ \\
\hline
\end{tabular}

MDA - malondialdehyde, oxidative stress marker and some antioxidant enzymes GPX - glutathione peroxidase, SOD superoxide dismutase, CAT - catalase. ${ }^{\mathrm{a}, \mathrm{b}, \mathrm{c}}$ Means in the same column (in either serum or tissue) followed by the different superscript are significantly different $(P<0.05)$ 
$(P<0.01)$ in the level of malondialdehyde $(-8.47$ and $-13.87 \%$ in serum, -5.74 and $-12.81 \%$ in tissue, respectively) compared to positive control (group 2). These results indicated that pretreatment with both selenium and nano-selenium for albino rats were very effective in the prevention of oxidative damage induced by cisplatin, which resulted in significantly lower $(P<0.01)$ MDA concentration.

Effect of different selenium forms on kidney functions enzymes. Serum creatinine. Effect of different treatments on serum creatinine level is shown in Fig. 1. There is a significant difference in the serum creatinine concentration for each group. In the cisplatin-injected group with nano-selenium, serum creatinine level reached the highest value $(2.5 \mathrm{mg} / \mathrm{dl})$ representing kidney failure. Followed by the cisplatin-injected group with selenium $(1.2 \mathrm{mg} / \mathrm{dl})$ which was in between that of both, nano-selenium group and the cisplatin group. Cisplatin-injected group has mild nephrotoxicity which was confirmed by a slight elevation of serum creatinine level $(1.09 \mathrm{mg} /$ $\mathrm{dl}$ ), while the control group was normal and healthy which is also confirmed by serum creatinine concentration $(0.6 \mathrm{mg} / \mathrm{dl})$.

Cisplatin injected at a dose of $6 \mathrm{mg} / \mathrm{kg}$ every 21 days for 70 days induced significant increase $(P<0.05)$ in the level serum creatinine $(81.67 \%)$ comparison to its corresponding control (group 1), while, administration of both selenium and nano-selenium at a dose of sodium selenite $0.1 \mathrm{mg} / \mathrm{kg}$ every 3 days for 70 days failed to improve this increase in creatinine concentration $(P<0.05)(10.09$ and $135.78 \%$, respectively) relative to positive control (group 2)

Serum urea. Urea is the nitrogenous waste product of protein breakdown. Almost all of it is eliminated principally from the body by the kidneys in urine and the measurement of its concentration is too much important for the assessment of kidney (renal) status. Serum urea concentrations in different experimental groups are shown in Fig. 1.

Injection of cisplatin $6 \mathrm{mg} / \mathrm{kg}$ every 21 days for 70 days induced significant increase $(P<0.05)$ in serum urea concentration $(40.29 \%)$ compared to their corresponding controls (group 1). Moreover, treatment of cisplatin-intoxicated rats with the selenium or nano-selenium at a dose of sodium selenite $0.1 \mathrm{mg} / \mathrm{kg}$ as selenium sources every 3 days for 70 days caused significant increase $(P<0.05)$ serum urea concentration (-70.41 and $92.71 \%$, respectively), compared to their corresponding control (group 2).
Serum urea concentration of negative control group was within the accepted range, which indicates normal and healthy renal condition.

The gradual increase in the measured values of urea concentrations in four groups (control, cisplatin, cisplatin plus selenium and finally, cisplatin plus nano-selenium respectively) is a good indicator of the toxic effect of the co-administration of selenium and nano-selenium with multiple doses of cisplatin. Cisplatin-injected group with nano-selenium showed the highest serum urea concentration $(102 \mathrm{mg} / \mathrm{dl})$ which indicated severe destructive vacuolar degenerative changes and severe toxicity of the co-administration of those two medicines over multiple cisplatin doses for the tumor treatment. The severity of the renal toxicity of the cisplatin-injected group with selenium is lower than that cisplatin-injected group followed by cisplatin-injected group with nano-selenium.

Histological study. Examination of the kidney sections of a control rat administered saline had the normal histological architecture of the kidney. Each section is formed of cortex, medulla and papilla. The cortex is formed of numerous Malpighian corpuscles beside proximal and distal tubules (Fig. 2,1). Each corpuscle has a tuft of glomerulus surrounded by a then Bowman's capsule. A urinary space is seen embraced between the glomerulus and this capsule (Fig. 2,1 and Fig. 2,2).

In cisplatin-injected group, numerous histological changes were cortical. The cortex has a cloudy swelling in the proximal and distal convoluted tubules (Fig. 2,3), while the medulla has inter tubular infiltration with mononuclear cells and dilatation of some renal tubular (Fig. 2,4).

Cisplatin-injected group with administration of selenium showed glomerular atrophy. Swelling and granulation of the cytoplasm of renal epithelium, also slight inter tubular infiltration with leukocyte (Fig. 2,5). While the medulla showed hyaline cast in some tubules. Few lymphocytic infiltrations were found between the tubules-mild dilatation in some tubules (Fig. 2,6). Finally, the cortex and medulla of the last group (cisplatin-injected group with administration of nano-selenium) indicated the interstitial nephrite (Fig. 2,7 and Fig. 2,8, respectively) checked increment in serum creatinine and histopathological changes including vacuolation, rot and protein throws were seen in proximal renal tubules in the second day after cisplatin infusion.

Most noticed renal histological lesions resulted from cisplatin injection were nearly increased after administration of either selenium treatments at a 

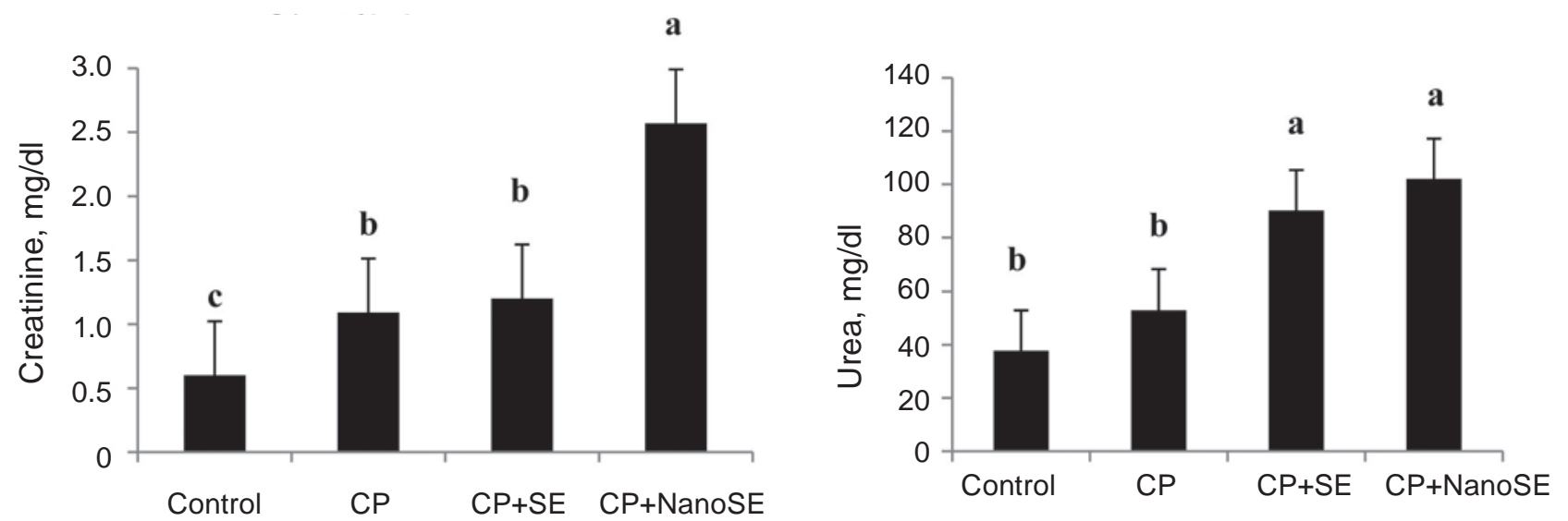

Fig. 1. Effect of selenium and nano-selenium on cisplatin-induced kidney dysfunctions. The data are represented by mean $\pm S E(n=9) .{ }^{a, b, c}$ Means of different superscript are significantly different $(P<0.05)$

dose of sodium selenite $0.1 \mathrm{mg} / \mathrm{kg}$, every 3 days for 70 days despite few mononuclear leucocytes noticed with the nano-selenium group.

In the present study, cisplatin caused tissue injury in the kidney through oxidative stress. The data obtained affirm that usage of cisplatin (CP) caused a critical increment of MDA level and decrease of catalase, glutathione peroxidase and superoxide dismutase in the serum and kidney tissue of rats (Table). CP-prompted free radical creation and MDA in cylindrical cells have been recommended to be in charge of the oxidative renal harm $[1,3,8$, 14]. CP influences renal tissues where created free radicals can connect with layer lipids to deliver their peroxidation, influencing cell structure and capacity $[2,17,18]$. Also, CP could advance the expansion in lipid peroxidation in vitro [36]. Helpful impacts of $\mathrm{CP}$ depend on the interaction with DNA in the cell, forestalling expansion, and instigating apoptosis in tumor cells. Cisplatin-induced mitochondrial reactive oxygen species (ROS) generation activated an inflammatory response, cell passing and kidney brokenness/nephropathy [37]. Cisplatin at first triggers oxidative stress in the mitochondria of kidney proximal rounded and endothelial cells, which is trailed by an optional flood of ROS/RNS (reactive nitrogen species) generation, disintegration of mitochondrial structure and capacity, an intense inflammatory response, histopathological damage and reduced renal capacity $[33,38]$. Acute poisoning of rats with $\mathrm{CP}$ significantly reduced activities of antioxidant enzymes (SOD, CAT, and GPX). The administration of cisplatin CP caused the decline of SOD and CAT activity in kidney tissue. The reduce SOD action is deficient to scavenge the superoxide anion, delive- red amid the typical metabolic procedure [39, 40]. Levels of CAT and GPX were likewise found to diminish after $\mathrm{CP}$ injection, resulting in diminished capacity of the kidney to scavenge toxic hydrogen peroxide $\left(\mathrm{H}_{2} \mathrm{O}_{2}\right)$ and lipid peroxides. Moreover, rats injected with cisplatin (group 2) showed a renal toxicity which was indicated by high level of urea and creatinine compared to control group (Fig. 1) and histological abnormalities of renal tissue (Fig. 2,3) and Fig. 2,4). Creatinine is a waste product that come from the breakdown of the creatine in the muscles. It is normally excreted from the body through nephrons (the structural and functional unit of the kidney). Its concentration in the serum is a good indicator of the health status of the kidney. Similar finding of abnormal in morphological alteration in the renal tissue caused by the cisplatin toxicity where the inner and outer medulla contain intotubure cats and tubular dilatation [33]. Urea can be the best evidence of renal function since a significant increase in the serum urea is due to high nitrogenous substances intake which was not noted in the experiment or the diminished renal excretion. The recorded increase in urea may be due to an increase in nitrogen retention and/or due to corrupted renal function [41, 42].

Creatinine is creatine anhydride and is formed by spontaneous and irreversible reaction during skeletal muscle metabolism. Serum creatinine is one of the kidney related variables that indicate renal toxicity [43]. An increase in serum creatinine is a biomarker of renal damage creatinine may be indicative of kidney-specific physiological disorders [44].

Clinical and exploratory examinations recommended that expanded oxidative stress related to an antioxidant activity like vitamine $\mathrm{E}, \mathrm{C}$ and selenium 

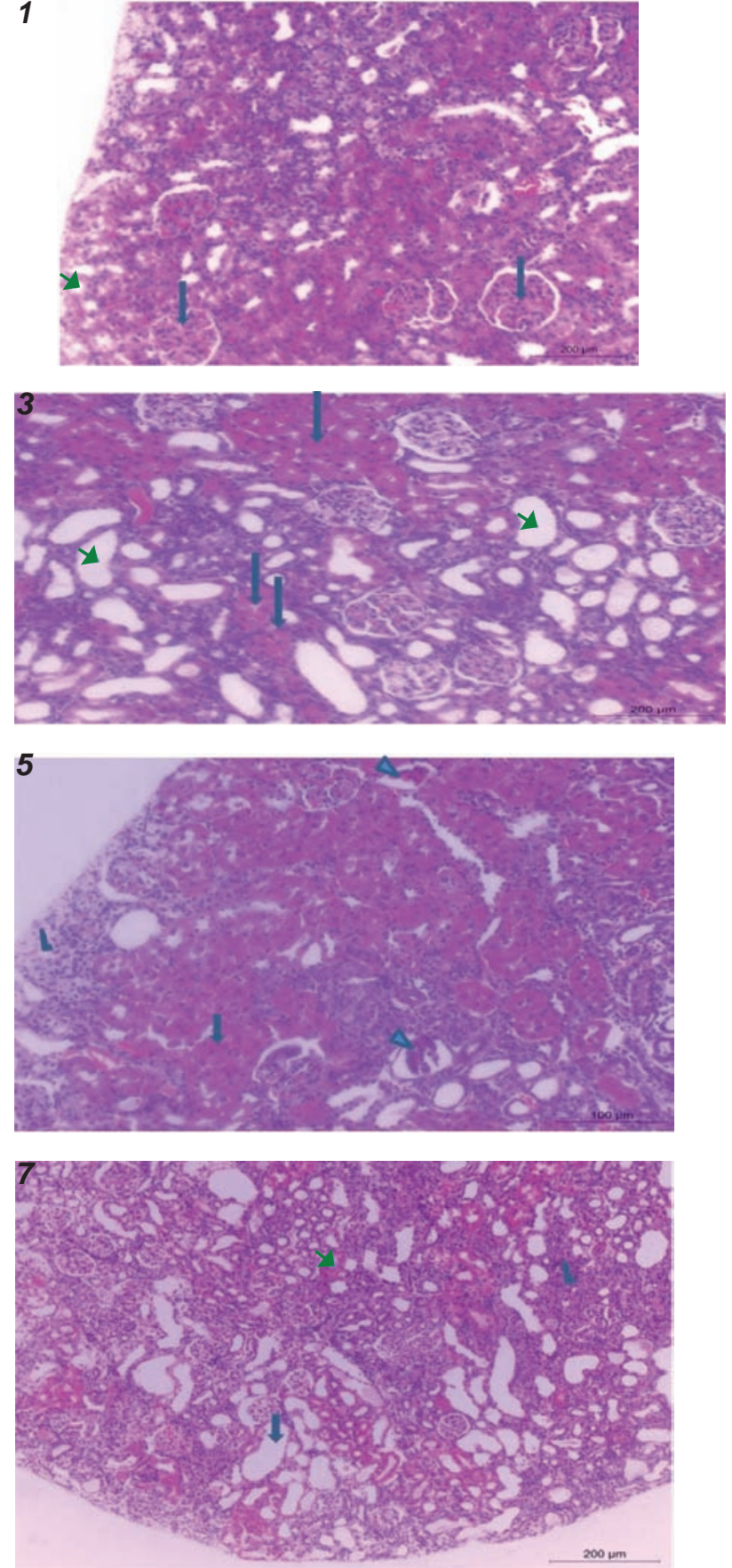
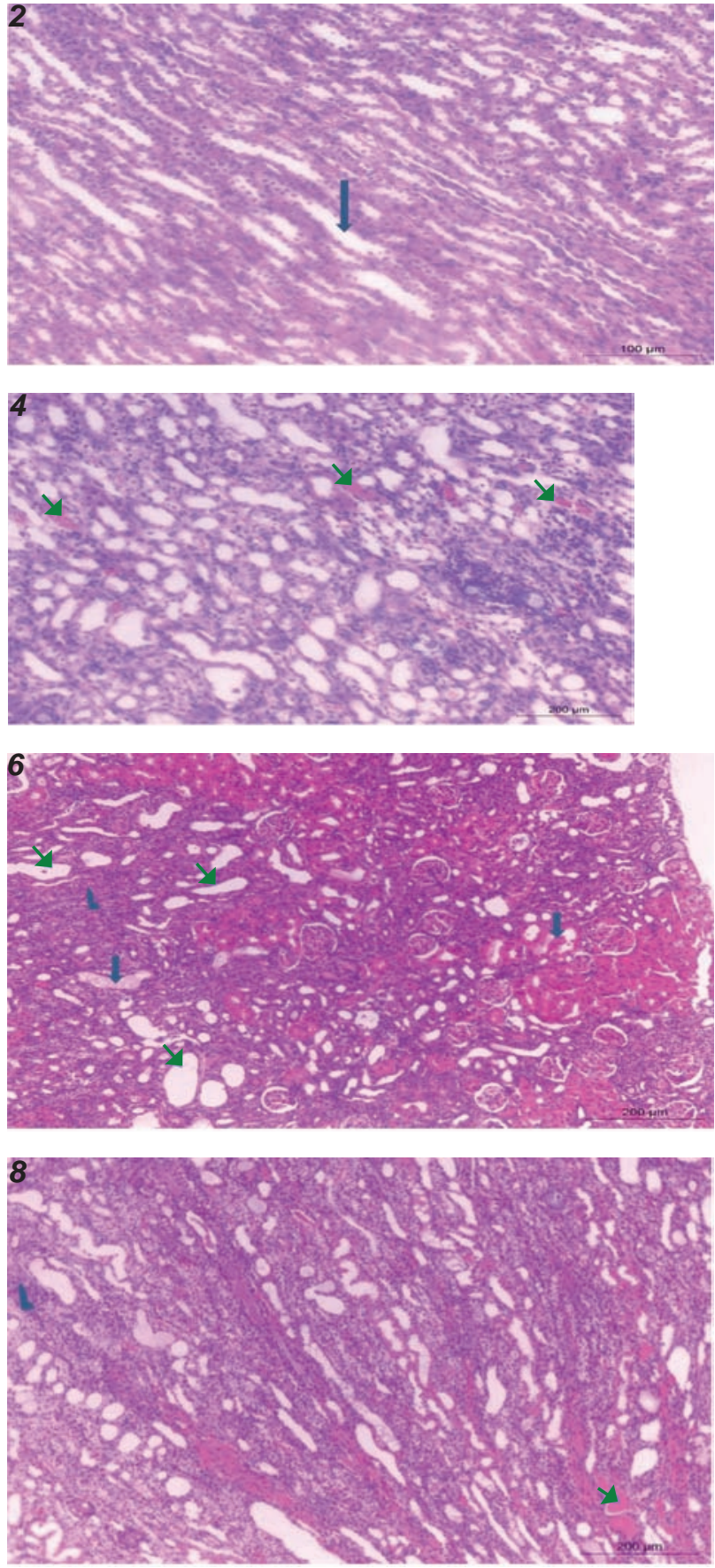

Fig. 2. Light micrograph of a kidney section (1 and 2) negative control; (3 and 4) positive control, cisplatin injected group; (5 and 6) cisplatin with selenium group; (7 and 8) cisplatin with nano-selenium group (H and $E \times 400$ ). 1 - Renal cortex showing normal renal corpuscles (blue arrow) and normal renal tubules (green arrow); $\mathbf{2}$-Renal medulla showing normal collecting tubules (blue arrow); $\mathbf{3}$-Renal cortex showing Cloudy swelling (blue arrow) in the proximal and distal convoluted tubules together with dilated tubules (green arrow); 4 -Renal medulla showing only congestion of some intertubular blood vessels (arrow); 5 -Renal cortex showing glomerular atrophy (arrow head), cloudy swelling in renal epithelium (arrow). Slight intertubular infiltration with leukocytes (L); 6 - Renal medulla showing hyaline cast in some tubules (blue arrow). Few leukocytic infiltration (L) between tubules and mild dilatation of some tubules (green arrow); 7 - Renal cortex showing interstitial nephrite (coaggulative necrosis green arrow; dilatation of renal tubules (blue arrow), lymphocytic cell infiltration (L); 8 - The medulla showing congestion;arrow, interstitial infiltration with lymphocytes (L) (interstitial nephrite). 
starts a course of responses in charge of cisplatinincited nephrotoxicity $[1,3,8,14]$. Selenium is a trace element that is highly used as antioxidant. The ameliorative effect of selenium against the cisplatin renal damage was demonstrated within a single dose. In the present investigation, the co-administration of selenium or nano-selenium with cisplatin caused a marked inhibition of the oxidative stress caused by cisplatin. This inhibition was proved by the measurement of the oxidation enzymes such as MDA, CAT, SOD and GPX in both serum and tissue (Table). Nano-selenium showed a higher protective effect against the oxidation process compared to a selenium. In animals receiving selenium or nanoselenium, the concentrations of CAT and SOD in the kidney were significantly increased compared to the animals which received $\mathrm{CP}$ only. These outcomes demonstrated that Se significantly lessens the exhaustion of GPX level antioxidant defence enzyme activity in the kidney of rats treated with CP. The defensive impacts of Se appear to be essentially connected with its essence in the GPX, which is known to shield DNA and other cellular components from harmful effect of ROS. This outcome demonstrates that the raise of MDA levels in the kidney tissue of rats treated with $\mathrm{CP}$ might be identified with the lessening in the action of GPX. Treatment with Se was exceptionally viable in the aversion of oxidative harm actuated by CP, which brought about significantly lower MDA levels in kidney tissue. GPX is an outstanding non-enzymatic antioxidant that gives the second line of protection against oxidative harm [45]. GPX goes about as a substrate for the glutathione peroxidase and glutathione-S-transferase enzymes, and is associated with the decrease/expulsion of ROS from cells [22]. Decreased concentration of GPX happens amid oxidative stress, which results in the disability of cell capacity and metabolism [23]. These outcomes can be clarified by the significant role of Se in preventing lipid peroxidation and in insurance of integrity and functioning of tissues and cells also the nano-selenium is more protective than selenium $[13,20,22,46]$.

Although, the beneficial uses of selenium as a trace element Se-intake needed to saturate glutathione peroxidase activity. Many researchers had approved that the selenium toxicity is an acute case resulting from the overdosing of the selenium administration or accumulation in the body [47]. As selenium is used in more chemoprevention and therapeutic settings, additional information on selenium species, sequestration of selenium in specific organs, excretion, and toxicities is needed [48].

It can be concluded that the use of selenium or nano-selenium plays an important role as an antioxidant, Its long term usage during the experiment may be a cause of toxicity in rats which followed by the increased in serum creatinine and urea and also caused the histopathological damage and inflammation of kidney tissues. Therefore, further studies should be made to explain the cause of the harmful effect of selenium or nano-selenium when treated with cisplatin for long term use.

Conflict of interest. Authors have completed the Unified Conflicts of Interest form at http://ukrbiochemjournal.org/wp-content/uploads/2018/12/ coi_disclosure.pdf and declare no conflict of interest.

\section{ВПЛИВ СЕЛЕНУ І НАНО-СЕЛЕНУ НА ІНДУКОВАНУ ЦИСПЛАТИНОМ НЕФРОТОКСИЧНІСТЬ У ЩУ РІВ- АЛЬБІНОСІВ}

\author{
M. M. A. Shafaee ${ }^{1}$, H.S. Mohamed ${ }^{2}$, \\ S. A. Ahmed ${ }^{1}$, M. A. Kandeil ${ }^{3}$
}

${ }^{1}$ Chemistry Department, Faculty of Science, Beni-Suef University, Egypt;

${ }^{2}$ Research Institute of Medicinal and Aromatic Plants, Beni-Suef University, Egypt;

${ }^{3}$ Biochemistry Department, Faculty of Veterinary Medicine, Beni-Suef University, Egypt; e-mail: husseinshaban@science.bsu.edu.eg

Цисплатин широко використовується в хіміотерапії для лікування деяких форм раку, але його застосування обмежене через побічну нефротоксичну дію. Раніше було виявлено позитивний вплив селену на токсичність цисплатину у разі короткочасних введень, хоча рекомендована схема прийому цисплатину за хіміотерапіїце багаторазове введення кожні три або чотири тижні залежно від типу пухлини. Метою цього дослідження було вивчити ефект застосування селену або нано-селену на індуковану цисплатином нефротоксичність у щурів-альбіносів. Сорок щурів було розділено на чотири рівні групи. Упродовж експериментального періоду (70 днів) тваринам цих груп вводили: 1 (контроль) фізіологічний розчин; 2 - цисплатин 6 мг/кг кожний 21-й день; 3 - цисплатин 6 мг/кг плюс в/м ін'єкція селену (у вигляді селеніту натрію) 
0,1 мг/кг кожні 3 дні; 4 - цисплатин 6 мг/кг плюс в/м ін'єкція нано-селену 0,1 мг/кг кожні 3 дні. Показано, що селен або нано-селен виявляв антиоксидантний ефект за рахунок підвищення рівня антиоксидантних ензимів як у сироватці крові, так і в нирковій тканині. Разом 3 тим, у щурів, які отримували цисплатин протягом експериментального періоду, спостерігали також негативний вплив на функцію нирок через підвищення в сироватці крові концентрації сечовини і креатиніну та аномальні морфологічні зміни в тканині нирок.

К л юч о в і с ло в а: селен, нано-селен, цисплатин, нефротоксичність.

\section{References}

1. Posner MR, Hershock DM, Blajman CR, Mickiewicz E, Winquist E, Gorbounova V, Tjulandin S, Shin DM, Cullen K, Ervin TJ, Murphy BA, Raez LE, Cohen RB, Spaulding M, Tishler RB, Roth B, Viroglio Rdel C, Venkatesan V, Romanov I, Agarwala S, Harter KW, Dugan M, Cmelak A, Markoe AM, Read PW, Steinbrenner L, Colevas AD, Norris CM Jr, Haddad RI. Cisplatin and fluorouracil alone or with docetaxel in head and neck cancer. N Engl J Med. 2007; 357(17): 17051715.

2. Vermorken JB, Remenar E, van Herpen C, Gorlia T, Mesia R, Degardin M, Stewart JS, Jelic S, Betka J, Preiss JH, van den Weyngaert D, Awada A, Cupissol D, Kienzer HR, Rey A, Desaunois I, Bernier J, Lefebvre JL. Cisplatin, fluorouracil, and docetaxel in unresectable head and neck cancer. $N$ Engl J Med. 2007; 357(17): 1695-1704.

3. Feldman DR, Ardeshir-Rouhani-Fard S, Monahan P, Sesso HD, Fung C, Williams AM, Hamilton RJ, Vaughn DJ, Beard CJ, Cook R, Zaid MA, Lipshultz SE, Einhorn LH, Oeffinger KC, Travis LB, Fossa SD. Predicting cardiovascular disease among testicular cancer survivors after modern cisplatin-based chemotherapy: application of the framingham risk score. Clin Genitourin Cancer. 2018; 16(4): e761-e769.

4. Selfe J, Goddard NC, McIntyre A, Taylor KR, Renshaw J, Popov SD, Thway K, Summersgill B, Huddart RA, Gilbert DC, Shipley JM. IGF1R signalling in testicular germ cell tumour cells impacts on cell survival and acquired cisplatin resistance. J Pathol. 2018; 244(2): 242-253.

5. Samuel P, Pink RC, Brooks SA, Carter DR. miRNAs and ovarian cancer: a miRiad of mechanisms to induce cisplatin drug resistance. Expert Rev Anticancer Ther. 2016; 16(1): 57-70.

6. Samuel P, Mulcahy LA, Furlong F, McCarthy HO, Brooks SA, Fabbri M, Pink RC, Carter DRF. Cisplatin induces the release of extracellular vesicles from ovarian cancer cells that can induce invasiveness and drug resistance in bystander cells. Philos Trans R Soc Lond B Biol Sci. 2018; 373(1737): 20170065.

7. Li Q, Damish AW, Frazier Z, Liu D, Reznichenko E, Kamburov A, Bell A, Zhao H, Jordan EJ, Gao SP, Ma J, Abbosh PH, Bellmunt J, Plimack ER, Lazaro JB, Solit DB, Bajorin D, Rosenberg JE, D'Andrea AD, Riaz N, Van Allen EM, Iyer G, Mouw KW. ERCC2 helicase domain mutations confer nucleotide excision repair deficiency and drive cisplatin sensitivity in muscle-invasive bladder cancer. Clin Cancer Res. 2019; 25(3): 977-988.

8. Plimack ER, Dunbrack RL, Brennan TA, Andrake MD, Zhou Y, Serebriiskii IG, Slifker M, Alpaugh K, Dulaimi E, Palma N, HoffmanCensits J, Bilusic M, Wong YN, Kutikov A, Viterbo R, Greenberg RE, Chen DY, Lallas CD, Trabulsi EJ, Yelensky R, McConkey DJ, Miller VA, Golemis EA, Ross EA. Defects in DNA repair genes Predict response to neoadjuvant cisplatin-based chemotherapy in muscle-invasive bladder cancer. Eur Urol. 2015; 68(6): 959-967.

9. Kleinberg LR, Catalano PJ, Forastiere AA, Keller SM, Mitchel EP, Anne PR, Benson AB $3^{\text {rd }}$. Eastern cooperative oncology Group and American college of radiology imaging network randomized phase 2 trial of neoadjuvant preoperative paclitaxel/cisplatin/ radiation therapy (RT) or irinotecan/cisplatin/ RT in esophageal adenocarcinoma: long-term outcome and implications for trial design. Int $J$ Radiat Oncol Biol Phys. 2016; 94(4): 738-746.

10. Chan D, Zhou Y, Chui CH, Lam KH, Law S, Chan AS, Li X, Lam AK, Tang JCO. Expression of insulin-like growth factor binding protein-5 (IGFBP5) reverses cisplatin-resistance in esophageal carcinoma. Cells. 2018; 7(10). pii: E143. 
11. Fennell DA, Summers Y, Cadranel J, Benepal T, Christoph DC, Lal R, Das M, Maxwell F, Visseren-Grul C, Ferry D. Cisplatin in the modern era: The backbone of first-line chemotherapy for non-small cell lung cancer. Cancer Treat Rev. 2016; 44: 42-50.

12. Senan S, Brade A, Wang LH, Vansteenkiste J, Dakhil S, Biesma B, Martinez Aguillo M, Aerts J, Govindan R, Rubio-Viqueira B, Lewanski C, Gandara D, Choy H, Mok T, Hossain A, Iscoe N, Treat J, Koustenis A, San Antonio B, Chouaki N, Vokes E. PROCLAIM: randomized phase III trial of pemetrexedcisplatin or etoposide-cisplatin plus thoracic radiation therapy followed by consolidation chemotherapy in locally advanced nonsquamous non-small-cell lung cancer. J Clin Oncol. 2016; 34(9): 953-962.

13. Hanigan $\mathrm{MH}$, Devarajan P. Cisplatin nephrotoxicity: molecular mechanisms. Cancer Ther. 2003; 1: 47-61.

14. Jordan P, Carmo-Fonseca M. Molecular mechanisms involved in cisplatin cytotoxicity. Cell Mol Life Sci. 2000; 57(8-9): 1229-1235.

15. Kröning $R$, Lichtenstein AK, Nagami GT. Sulfur-containing amino acids decrease cisplatin cytotoxicity and uptake in renal tubule epithelial cell lines. Cancer Chemother Pharmacol. 2000; 45(1): 43-49.

16. Shalkami AS, Hassan MIA, Abd El-Ghany AA. Perindopril regulates the inflammatory mediators, NF- $\kappa \mathrm{B} / \mathrm{TNF}-\alpha / \mathrm{IL}-6$, and apoptosis in cisplatin-induced renal dysfunction. Naunyn Schmiedebergs Arch Pharmacol. 2018; 391(11): 1247-1255.

17. Sadowitz PD, Hubbard BA, Dabrowiak JC, Goodisman J, Tacka KA, Aktas MK, Cunningham MJ, Dubowy RL, Souid AK. Kinetics of cisplatin binding to cellular DNA and modulations by thiol-blocking agents and thiol drugs. Drug Metab Dispos. 2002; 30(2): 183-190.

18. Cohen SM, Lippard SJ. Cisplatin: from DNA damage to cancer chemotherapy. Prog Nucleic Acid Res Mol Biol. 2001; 67: 93-130.

19. Mora Lde O, Antunes LM, Francescato HD, Bianchi Mde L. The effects of oral glutamine on cisplatin-induced nephrotoxicity in rats. Pharmacol Res. 2003; 47(6): 517-522.
20. Razzaque MS. Cisplatin nephropathy: is cytotoxicity avoidable? Nephrol Dial Transplant. 2007; 22(8): 2112-2116.

21. Taguchi T, Nazneen A, Abid MR, Razzaque MS. Cisplatin-associated nephrotoxicity and pathological events. Contrib Nephrol. 2005; 148: 107-121.

22. Cetin R, Devrim E, Kiliçoğlu B, Avci A, Candir O, Durak I. Cisplatin impairs antioxidant system and causes oxidation in rat kidney tissues: possible protective roles of natural antioxidant foods. J Appl Toxicol. 2006; 26(1): 42-46.

23. Zhang JG, Lindup WE. Role of mitochondria in cisplatin-induced oxidative damage exhibited by rat renal cortical slices. Biochem Pharmacol. 1993; 45(11): 2215-2222.

24. Baraboy VA, Shestakova EN. Selenium: the biological role and antioxidant activity. $U k r$ Biokhim Zhurn. 2004; 76(1): 23-32. (In Russian).

25. Khurana A, Tekula S, Saifi MA, Venkatesh P, Godugu C. Therapeutic applications of selenium nanoparticles. Biomed Pharmacother. 2019; 111: 802-812.

26. Onanuga K, Begley U, Begley TJ. Understanting the role of selenium in reactive oxygen species management in colorectal cancers. Free Radic Biol Med. 2016; 100(Suppl): S127-S128.

27. Yang Y, Liu H, Liu F, Dong Z. Mitochondrial dysregulation and protection in cisplatin nephrotoxicity. Arch Toxicol. 2014; 88(6): 12491256.

28. Chakraborty P, Roy SS, Sk UH, Bhattacharya S. Amelioration of cisplatin-induced nephrotoxicity in mice by oral administration of diphenylmethyl selenocyanate. Free Radic Res. 2011; 45(2): 177187.

29. Ghosh P, Roy SS, Chakraborty P, Ghosh S, Bhattacharya S. Effects of organoselenium compound 2-(5-selenocyanato-pentyl)benzo[de]isoquinoline 1,3-dione on cisplatin induced nephrotoxicity and genotoxicity: an investigation of the influence of the compound on oxidative stress and antioxidant enzyme system. BioMetals. 2013; 26(1): 61-73.

30. Xu C, Qiao L, Ma L, Guo Y, Dou X, Yan S, Zhang B, Roman A. Biogenic selenium nanoparticles synthesized by Lactobacillus casei ATCC 393 alleviate intestinal epithelial barrier dysfunction caused by oxidative stress via Nrf2 
signaling-mediated mitochondrial pathway. Int $J$ Nanomedicine. 2019; 14: 4491-4502.

31. Naziroglu M, Karaoğlu A, Aksoy AO. Selenium and high dose vitamin $\mathrm{E}$ administration protects cisplatin-induced oxidative damage to renal, liver and lens tissues in rats. Toxicology. 2004; 195(2-3): 221-230.

32. Ognjanović BI, Djordjević NZ, Matić MM, Obradović JM, Mladenović JM, Stajn AS̆, Saičić ZS. Lipid peroxidative damage on Cisplatin exposure and alterations in antioxidant defense system in rat kidneys: a possible protective effect of selenium. Int J Mol Sci. 2012; 13(2): 1790-1803.

33. Francescato HD, Costa RS, Rodrigues Camargo SM, Zanetti MA, Lavrador MA, Bianchi MD. Effect of oral selenium administration on cisplatin-induced nephrotoxicity in rats. Pharmacol Res. 2001; 43(1): 7782.

34. Ohkawa H, Ohishi N, Yagi K. Assay for lipid peroxides in animal tissues by thiobarbituric acid reaction. Anal Biochem. 1979; 95(2): 351358.

35. Paglia DE, Valentine WN. Studies on the quantitative and qualitative characterization of erythrocyte glutathione peroxidase. J Lab Clin Med. 1967; 70(1): 158-169.

36. Kim YK, Jung JS, Lee SH, Kim YW. Effects of antioxidants and $\mathrm{Ca}^{2+}$ in cisplatin-induced cell injury in rabbit renal cortical slices. Toxicol Appl Pharmacol. 1997; 146(2): 261-269.

37. Mukhopadhyay $\mathrm{P}$, Horváth $\mathrm{B}$, Zsengellér Z, Zielonka J, Tanchian G, Holovac E, Kechrid M, Patel V, Stillman IE, Parikh SM, Joseph J, Kalyanaraman B, Pacher P. Mitochondrialtargeted antioxidants represent a promising approach for prevention of cisplatin-induced nephropathy. Free Radic Biol Med. 2012; 52(2): 497-506.

38. Mansour MA, Nagi MN, El-Khatib AS, AlBekairi AM. Effects of thymoquinone on antioxidant enzyme activities, lipid peroxidation and DT-diaphorase in different tissues of mice: a possible mechanism of action. Cell Biochem Funct. 2002; 20(2): 143-151.

39. Ateşşahin A, Sahna E, Türk G, Ceribaşi AO, Yilmaz S, Yüce A, Bulmuş O. Chemoprotective effect of melatonin against cisplatin-induced testicular toxicity in rats. J Pineal Res. 2006; 41(1): 21-27.

40. Matés JM. Effects of antioxidant enzymes in the molecular control of reactive oxygen species toxicology. Toxicology. 2000; 153(1-3): 83-104.

41. Kaneko S, Feinstone SM, Miller RH. Rapid and sensitive method for the detection of serum hepatitis B virus DNA using the polymerase chain reaction technique. J Clin Microbiol. 1989; 27(9): 1930-1933.

42. Patent US5086764A. Gilman T. Absorbent dressing. Publ. 1992.

43. Kyle RA, Greipp PR. Amyloidosis (AL). Clinical and laboratory features in 229 cases. Mayo Clin Proc. 1983; 58(10): 665-683.

44. Sánchez-Chardi A, Marques CC, Nadal J, da Luz Mathias M. Metal bioaccumulation in the greater white-toothed shrew, Crocidura russula, inhabiting an abandoned pyrite mine site. Chemosphere. 2007; 67(1): 121-130.

45. Ramesh G, Reeves WB. Salicylate reduces cisplatin nephrotoxicity by inhibition of tumor necrosis factor-alpha. Kidney Int. 2004; 65(2): 490-499.

46. Combs GF Jr, Gray WP. Chemopreventive agents: selenium. Pharmacol Ther. 1998; 79(3): 179-192.

47. Morris JS, Crane SB. Selenium toxicity from a misformulated dietary supplement, adverse health effects, and the temporal response in the nail biologic monitor. Nutrients. 2013; 5(4): 1024-1057.

48. Reid ME, Stratton MS, Lillico AJ, Fakih M, Natarajan R, Clark LC, Marshall JR. A report of high-dose selenium supplementation: response and toxicities. J Trace Elem Med Biol. 2004; 18(1): 69-74. 